\title{
Western aid workers in Cambodian hospitals
}

\section{Ethical, professional and social divergences}

\author{
Anne Yvonne Guillou
}

\begin{abstract}
Since the Khmer Rouge genocide (1975-79), Cambodia has been constructed as a victim par excellence, which exists only through Western financial aid and compassion. In this ideological context, non-governmental organizations (NGOs) mushroomed by the hundreds in the 1980s in the refugee camps along the Cambodia-Thailand border. They then flowed into Cambodia during the repatriation process under UNHCR supervision in the early 1990s. Because of the financial weakness of the Cambodian government at that time (when support from the USSR and other socialist countries abruptly ceased), the NGOs gained a powerful position as institutional partners of the government. Taking the example of the medical sector, this article analyses humanitarian ideology and its implementation in Cambodian hospitals in the 1990s. The author explores the contradiction between the Westerners' 'philosophy of development' versus the Cambodians' 'ethic of gift', based on an ethnographical account of the daily activities in Cambodian hospitals, from an interactionist perspective. The author observes the interactions between the Cambodian staff, the humanitarian NGO staff, the patients and their families, showing how the divergence of moral values, the historical construction of the medical profession and social games create conflict between the humanitarians and the Cambodians. This has a direct impact on the patient-physician relationship. Finally, while millions of dollars and thousands of hours of humanitarian work have been spent in Cambodia, some major public health indices have not been greatly improved.
\end{abstract}

Keywords: medical anthropology; aid; ethics; Buddhism; Cambodia; NGOs

Author details: Dr Anne Yvonne Guillou is an anthropologist and tenured researcher at Centre Asie du Sud-Est (CASE), Centre National de la Recherche Scientifique, 190 avenue de France, 75244 Paris Cedex 13, France. E-mail: anne.guillou@cnrs.fr.

\section{Establishing Cambodia as a victim}

Westerners' perceptions of so-called 'developing countries' have fundamentally changed during the past 20 years. Until the 1980s, young people in search of adventure set off with their backpacks for a year or two to hitch-hike or travel by bus through Africa or Asia, stopping for a few weeks on the way to work and earn enough money to continue their journey. Today, the children and grandchildren of these young travellers are still eager to discover new countries, but they are taken on by non-governmental organizations (NGOs) to teach Malian village women to read, or to hand out medicines in a Sri Lankan infirmary. The former 'Third World' is a site for self-discovery via the alleviation of poverty. Discovery of the Other is 
no longer considered to be enough: the Other must be saved. In the 'deployment of moral feelings in contemporary politics', in 'the tension between inequality and solidarity' (since the recipient of humanitarian aid is always indebted to the benefactor) (Fassin, 2011), Cambodia occupies a prime position in the twentyfirst century humanitarian imagination. It has been constructed as the choice victim and the choice recipient of humanitarian aid since the Khmer Rouge genocide (1975-79).

There are many explanations for this state of affairs. First was the Westerners' shock at the terrible failure of Democratic Kampuchea (or the 'Khmer Rouge regime') in the wake of the Vietnamese liberation war that led to communist victories in Saigon and Phnom Penh within two weeks of each other. The first eye-witness accounts of the atrocities and the terrible famines that decimated the Cambodian population reached the West in 1977 (Ponchaud, 1978), but only really attracted the attention of the media from 1979 onwards (in parallel with the tragedy of the Vietnamese boat people) when Vietnamese troops ousted the Khmer Rouge from power, leading to a vast exodus towards the Thai border and the setting up of the first refugee camps. As far as Cambodia is concerned, the partial depoliticization of aid organizations ${ }^{1}$ and the elevation of humanitarian ideology as universal morality (helping suffering people regardless of what side they are on) are possibly the result of the guilty conscience of the Western left wing after discovering the harmful effects of a regime that they had acclaimed a few years earlier. In 1979 and 1980, Western emotion at the sight of survivors arriving in the refugee camps increased with the threat of another famine within Cambodia, threatening the Cambodian population with total extinction. A large-scale international movement in favour of humanitarian intervention on the border was then set up and volunteers from all over the world flooded in to help the United Nations Organization (UNO) and the International Committee of the Red Cross (ICRC). The first NGOs, such as Médecins sans Frontières, the International Rescue Committee and the Thai Baptist Mission, were joined by many others in the dozen refugee camps controlled by the different Cambodian factions or by international organizations. Thus, by the beginning of 1980, there were no fewer than 95 nongovernmental organizations working in the fields of health and education (Shawcross, 1984).

Paradoxically, the massive NGO presence in Cambodia increased after the conflict between the four politico-military factions in Cambodia ${ }^{2}$ was resolved in 1991. 'The "humanitarian ideology" born from the ruins of third-world ideology' (Atlani-Duault, 2009) then defined the different stages of its intervention by introducing the ideas of 'emergency' and 'sustainable development'. ${ }^{3}$ After the 1993 elections, the UN High Commissioner for Refugees (UNHCR) organized the repatriation of the 360,000 refugees from the camps. The NGOs that had specialized in refugee support prepared to follow them into Cambodia, where they swelled

Only partial, because reception committees for South East Asian refugees in France were often set up by Indochinese war veterans, who were pleased to see in the influx of refugees the confirmation of their hatred of Communism. In the USA, reception committees were partly organized by former military personnel from the pro-American Lon-Nol regime (Chan, 2004).

2 These four factions were the Khmer Rouge movement (Democratic Kampuchea), Prince Sihanouk's party (FUNCINPEC), the nationalist Sonsannist Front (FLNK) and the Phnom Penh government (State of Cambodia).

My translation from the French. 
the ranks of the few that had been given permission to work in the country during the 1980s. In 1986, only 13 NGOs were working inside the country. In 1994, there were $127 .{ }^{4}$ Half of these NGOs specialized in a particular field, such as help for vulnerable populations (16.5\%), medicine (14.5\%), village development $(9.5 \%)$, education $(8.5 \%)$ and agriculture $(4.5 \%)$. The other organizations belonged to a field I would term 'charitable', and answered the immediate needs of a population allegedly in distress. Their staff, in contrast to those working for specialist NGOs, seldom had any professional training relevant to their activities. There were few very small charitable organizations in Cambodia, where only $7 \%$ declared an annual budget of less than $\$ 100,000$ in 1994 . Existing side by side with the 'professional' tradition that dates from the 1970s, the Christian charitable tradition $^{5}$ remained strong, represented in equal parts by Catholics - generally European - and Protestants - most often North American. Finally, national origin - Western or Japanese - added a further element of diversity to the NGO picture. Apart from the 10 recently arrived Japanese NGOs, representing 10\% of organizations, national origin was distributed as follows: 38\% European NGOs, 23\% North American (to which must be added 6\% Australian organizations) and 19\% Cambodian, with international organizations making up $4 \%$ of the total. This massive presence created a humanitarian 'arena' in which the numerous actors of the NGOs and local development agents interacted, all developing their own strategies within the framework of power relationships structured by the social and political context (Olivier de Sardan, 2005), especially in Cambodia.

The situation of NGOs in Cambodia in the 1990s was specific, due not only to their vast numbers, but also to the unusual position of power and legitimacy that they enjoyed on account of the weakness of the Cambodian state. At the end of the 1980s, aid from the USSR and other socialist countries was abruptly withdrawn, and Vietnamese troops were officially recalled in September 1989. Health and education services, officially free, found themselves completely without resources, leaving the field open for the NGOs. These organizations did not provide classic development aid, but undertook a veritable reconstruction, putting them in the position of institutional representatives at the highest level of government hierarchy. ${ }^{6}$ Whole sectors of public services were 'subcontracted' to aid organizations without any real consultation.

Despite massive humanitarian aid lasting a decade and several reforms of the public health service, health indicators do not appear to have greatly improved in the first decade of the twenty-first century: 'despite a few successes [slowing the progression of the AIDS epidemic, eradication of polio, increased life expectancy] the slow rate of progress achieved never ceases to astound even the most hardened professionals in the charity business' (Crochet, 2008, p 415). Malaria, diarrhoea in children, maternal deaths (347 per 100,000), undernourishment and tuberculosis (a disease associated with AIDS) are all still common. In this article,

4 This census is not exhaustive; it is the number of member organizations of the Cooperation Committee for Cambodia, which includes the majority of NGOs. From Cooperation Committee for Cambodia (1994) Directory of Humanitarian Assistance in Cambodia, Phnom Penh.

5 Only two Cambodian Buddhist NGOs and a few Muslim NGOs were listed in 1994. They did not intervene in the medical field.

$6 \quad$ Favoured by the pyramidal structure of public services in a single-party regime. It denies almost all powers of decision to bodies other than the Council of Ministers, which deals with even the most mundane matters. 
I analyse from an anthropological point of view some of the reasons for this failure.

\section{Studying medicine and humanitarians}

The situation described above was the one I discovered when I went to live in Cambodia in the early 1990s. I wished to study in greater depth the questions of social change and acculturation (meaning the adaptation of original cultural perceptions of the body and disease to a new environment) in the field of medicine. A more basic question guided my approach - that of local appropriation of a scientific practice claiming to be universal - namely, scientific medicine. Why and how was biomedicine $^{7}$ practised differently in Paris, Moscow and Phnom Penh? The field study I conducted during the early 1990s enabled me to observe actual medical practices in hospitals, using a method inspired by interactionism developed in sociology by Everett Hughes (1958), Anselme Strauss (1978) and Erving Goffman (1967). During this time, I observed various hospitals in Cambodia and refugee camps in Thailand. From village infirmaries to the central hospital in Phnom Penh, I made diversity my priority. The NGOs helping these establishments were themselves chosen for their diversity: professional or charitable, European, American or Japanese. As a general rule, I was introduced to the Cambodian hospital staff by an NGO doctor or nurse. Then I asked permission from the hospital management to stay in the hospital (sometimes even overnight, when I became quite close to the medical staff), saying that I wanted to acquaint myself with their activity for a study I was conducting for a university in France. I completed this survey by means of 12 more formal interviews with those in charge of hospitals in Phnom Penh.

The hospitals, which functioned more or less efficiently at the time, were all supported by foreign NGOs. The financial position of the Cambodian state was so disastrous that only health facilities helped by relief agencies accepted patients; the others existed for a few days a month when supplies were received from the Ministry of Health. It was not long before I noticed deep-seated, permanent misunderstandings between foreign aid workers and Cambodian medical staff. Although I was asked to do so, I refused to play the role of 'cultural mediator' generally assigned to the anthropologist by Western medical professionals, which consisted of explaining dysfunctional hospitals and disgruntled patients in terms of specific cultural features. Instead, I applied the theoretical model of interactionism, considering that medical practices in hospitals were the product of interactions between all actors present in the hospital - foreign doctors and their Cambodian colleagues, hospital management and those in charge of relief agencies, patients and their omnipresent families, foreign nurses and those from charitable organizations.

This article aims to contribute to the understanding of the mechanics of humanitarian aid and its limits, using observations made at the micro-social level. Since the first decade of the twenty-first century, the place occupied by Western relief agencies has of course evolved, due to various factors such as the increasing weight of bilateral and multilateral aid, the development of local $\mathrm{NGOs}^{8}$ (which

'Biomedicine' is a common term in medical anthropology and designates scientific medicine. 'The number of local NGOs and associations [...] continues to rise. In 2002, there were almost 400 local NGOs and nearly 600 associations registered with the Royal Government of Cambodia, which is a dramatic increase from 1991 when the first local NGO was established.' (Ke, 2011) 
nevertheless rely on foreign NGOs), the strengthening of the government's institutional capacities, in particular the rise of a new generation of Cambodian graduates trained abroad and capable of conducting development policies, and finally, the Cambodian government's reassessment of the weight of NGOs in Cambodia, and its desire to control them. ${ }^{9}$ However, in spite of these developments, relationships between Cambodian and foreign medical staff continue on much the same terms, and the number of foreign NGOs has increased considerably, reaching about 200 in 2010 (Ke, 2011). This sector, central to Cambodian economic activity, now employs 13,000 Cambodians (ibid).

\section{Medical ethics as a historical, social and religious product}

\section{Construction of medical professions}

In hospitals, one of the major points of conflict between Westerners and Cambodians is that of medical ethics. It is a subject leading to painful misunderstandings and is very badly experienced by the former group since they have profoundly interiorized the values that it represents, on which their professional identity is based. Sociologists and historians have shown how the medical profession was built up progressively in the West thanks to the slow conquest of its autonomy, the control over all therapeutic activities such as delivery and nursing, and finally, to the extension of its powers to numerous fields related to the body (sexual life, procreation, nutrition, child-rearing, etc) (Freidson, 1970; Starr, 1982). This rise in power was accompanied by strong social legitimacy won over the course of history thanks to the strong corporate identity of doctors, who showed themselves capable of persuading the state and society as a whole of the validity of their monopoly and the excellence of their practices. The values that, little by little, inspired confidence and respect, allowing doctors to occupy a position similar to that of the Catholic clergy a few decades earlier, became focused around medical ethics. Ideally, this implies not only a certain 'affective neutrality' with respect to the patient, but also the 'universalism' of medical practices (the doctor's interest in his or her patient is the result of his or her position as a patient, rather than his or her social or other qualities) and finally, being 'community-oriented' (the doctor is supposed to act for the general good, in a disinterested way) (Parsons, 1951). These medical ethics, recommended and practised by NGO aid workers, and considered to be universal and timeless, are at the heart of daily negotiations with their Cambodian colleagues.

Cambodian doctors are themselves the product of a very different historical process, made up of abrupt changes imposed by successive regimes. Scientific medicine, introduced during the French Protectorate of Cambodia, is practised on a very modest scale, from the point of view of both treatment and medical training, which attracts very few young Cambodians (Guillou, 2009; Ovesen and Trankell, 2010; Au, 2011). Under the Sihanouk government during the years of independence (1953) until the beginning of the war at the start of the 1970s, doctors managed as best they could to occupy a social position as 'civil servant-entrepre-

See the dispute between NGOs and the government concerning the Law on Association and NonGovernmental Organization (LANGO) draft law, whose fourth version was submitted in January 2012. 
neurs'. As civil servants employed by the Cambodian state, they often married the daughters of tradesmen of Chinese origin to form an urban bourgeoisie, which nevertheless had trouble organizing itself professionally and playing a role in political or social life. Post-colonial Cambodia built itself up around modernized Buddhism and reinterpreted monarchy, not around scientific practices and Western ideologies. The years of conflict, followed by the Khmer Rouge regime (1975-79), which was very hostile to this urban elite, put an end to this short-term development. When the People's Republic of Kampuchea was established under the aegis of Vietnam after the fall of the Khmer Rouge regime in 1979, all available goodwill was called upon and the medical profession was reconstructed from odds and ends, made up of surviving doctors and nurses, former students and many other volunteers. This splitting up went hand in hand with a pronounced political unification under the authority of the only political party, the Cambodian People's Party. These were the medical professionals that aid workers encountered at the beginning of the 1990s.

\section{Development philosophy versus the ethics of giving}

While humanitarian ideology has been superimposed on Western professional values in NGOs' practices, this contrasts strongly with the values guiding Cambodian health professionals. This divergence could be summed up as an opposition between development philosophy and the ethics of giving.

During the 1990s, this development philosophy was based on the fundamental principle that development aid should strengthen existing structures rather than create new ones. Action programmes consisted of helping hospitals by renovating premises, providing equipment and medicines, and supervising the medical work performed by Cambodians. The key principle of these programmes was that of 'sustainable development', which, in the course of a few years, would enable the hospital to provide an acceptable level of care and operate independently from the point of view of both equipment and human resources, without the help of foreigners. This implies providing help very progressively, avoiding giving the hospital more than its staff can manage, and respecting its absorptive capacity. The rule is therefore to stick to a level of care compatible with the capacity of the hospital and its staff - these imperatives are in line with the aims of primary health care, which still strongly influenced the practices of NGOs in the 1990s. They involve choosing realistic and effective management of scarce hospital resources (both material and human), based on a strengthening of human potential (via training), since, in humanitarian ideology, this represents a more important factor of development than the material environment.

This principle is part of a more general philosophy of development that assumes that everybody - starting with the Cambodians - should 'roll up their sleeves' for the common good and make a personal contribution whose fervour increases in direct proportion to the scarcity of the hospital's material resources. This moral concept is reinforced by economic considerations, since NGOs are also hampered by the limits of their budget - especially if they are small-scale organizations and, in their negotiations with the hospitals where they intervene, try to involve their Cambodian partners in medical expenses so that the entire weight of the hospital's financial operation does not rest on their shoulders alone. However, one of the major points of negotiation between aid agencies and Cambodians 
resides in the control of financial aid and hospital work. In other words, the Cambodians would like aid workers to make unconditional gifts in the traditional manner, whereas the aid agencies want to control the use of their money and involve the Cambodians more closely.

'Rolling up one's sleeves' and 'making a personal contribution'... these phrases remind us of the still recent period of collective labour in the People's Republic of Kampuchea, and further back in time, the slogans of the Khmer Rouge regime, which counted above all on human labour to perform the 'super great leap forward'. The Cambodian health workers that I met in hospitals, on the contrary, wanted aid organizations to play the role of benefactors rather than that of guides. However, these ethics of giving, according to the Buddhist model, are far removed from the development philosophy formulated by NGOs. The role of the benefactor, socially defined in Cambodian society, consists of the 'rich' giving to the 'poor'. All the leaders of successive regimes, starting with King Sihanouk himself, have, in front of the TV cameras, performed the compulsory activity associated with high social status, of distributing bags of rice and pieces of clothing to a crowd of respectfully squatting peasants during national festivals or after natural disasters such as floods, which occur frequently in Cambodia. This symbolic redistribution of wealth is a secular form of the Buddhist offering, which, for the faithful, consists of giving gifts to monks on numerous occasions. Offerings to monks, in the Theravada Buddhism practised in Cambodia, are the main way of acquiring merit [bon], enabling the donor to improve his life in a future existence, according to the theory of the reward of merit [karma]. In Cambodian society, as in other Theravadin societies, gifts have a threefold importance - that of honouring the donor, of enabling him or her to accumulate Buddhist merits and of providing material benefit to the recipient. Once this gift is given, the benefactor no longer has any control over it, in contrast to the gifts made by NGOs. Sometimes, the reticence of Western NGOs to provide abundant quantities of medicines and equipment is not appreciated, consequently diminishing their legitimacy and leading to conflicts.

In the 1990s, the main worry of Cambodian doctors and nurses was the very small salaries paid by the state, which were not enough to live on. Like all civil servants, they were paid about $\$ 25$ a month, whereas $\$ 100$ were needed to allow the average urban family to live decently. The perks (rice, care, housing) that they received from their membership of the civil service, which were appreciated a decade earlier when the country was experiencing extreme shortages, no longer appeared sufficient. After working for practically nothing for a decade, the doctors said that they now hoped to benefit from the nascent liberalization of the economy and regain their well-off middle class social status. During an interview, one Khmer doctor told me, as a joke, 'The real aid workers are us! We had no choice but to work for nothing for years. Now, we even have to pay for our own surgical thread or bandages if the patient can't pay and the hospital stores are empty!'

Single medical staff, in particular, had to prepare for the major financial effort represented by marriage negotiations and weddings themselves, saving the required sum, banknote by banknote, and taking advantage of every opportunity to make some money. These opportunities took the form of presents, spontaneously given by patients or requested from them more or less urgently, or indirect pay- 
ments provided by NGOs themselves (per diem payments received for training courses, medicines or minor medical supplies), or the opening of medical practices or private consultations carried out in hospitals or at home. In this way, they obtained unofficial income (completing the larger income of a wife involved in business), which placed them in the upper income bracket of the nascent middle classes. Differences in income were considerable, since economic situations differed according to positions obtained. Top managers occupying key positions in the Faculty of Medicine, the Ministry of Health and hospitals - positions obtained after both political and financial negotiations - were able to earn, on average, several thousand dollars a month in the 1990s. The first new cars - symbols of upward mobility - appeared. Doctors working in ordinary hospital jobs were able to earn several hundred dollars (from 100 to about 500 before the massive inflation caused by the arrival of the United Nations in 1993).

In the hope of making up for lost time, doctors agreed to perform the more or less 'voluntary' work of their hospital jobs, as long as it was not too time-consuming. The cumbersome control of the state party was less and less well tolerated as the years went by. Gradually, a tacit agreement was reached between hospital management and staff regarding the absence of medical personnel. During this period of transition, the Cambodian state wanted to retain its credibility by keeping up the appearance of a free, accessible-to-all public health service, while turning a blind eye to the sums paid by patients and the misappropriation of medicines, seen by the Cambodians as supplementary income. Civil servants had to derive the main part of their salary from activities outside their official position. In this regard, I met a doctor who taught French and managed a restaurant in addition to his consulting hours, which he reduced to a minimum. In this mug's game, the NGOs were put in an awkward position since they did not have a free hand to improve the quality of care as they would have wished.

Apart from these differing assessments of the meaning of humanitarian aid and hospital work, divergences are of an ethical and moral nature. The mutual feelings of patients and doctors must be analysed, not only via direct observations and interviews, but also in light of the values that form the basis of society and become apparent to the observer in the long term.

\section{Khmer affective economy: the Buddhist concepts of 'suffering' [dukkha] and 'universal benevolence' [karunā]}

The sight of another's suffering may give rise to different attitudes, such as 'pity' (which assumes two unequal classes of individuals, one of which, the impoverished mass, is subjected to the scrutiny of the other), or 'compassion', which, in the vocabulary of Hannah Arendt, only applies, on the contrary, to suffering individuals (Boltanski, 1999; Boltanski, citing Arendt, 1963). Western humanitarian medical ethics, as seen in the Cambodian hospitals where I was an observer, recommend compassion. Etymologically, this consists of 'suffering with': that is, 'taking part in another's suffering' (from the Late Latin com 'together' and pati 'to suffer'). One must imagine oneself in the place of the person who is suffering and identify oneself with him/her. However, 'compassion' thus defined is not part of the Cambodian affective economy, which is based on different principles. These are derived from Theravada Buddhism, which strongly influences representations of the world and the individual. This is why I will use the term 'universal bene- 
volence' rather than that of 'Buddhist compassion' to translate karunā since, in Theravada, 'sharing suffering' is a nonsense if one goes back to the meaning of the fundamental Buddhist concepts of dukkha and karunā. The former is a Pali term usually translated as 'suffering', but which in fact covers different levels of abstraction at the heart of primitive Buddhist thought. ${ }^{10}$ It is true that $d u k k h a$ is first of all the ordinary experiences of illness, old age, bereavement and all the other unpleasant experiences that an individual may undergo. This is the meaning that $t u k$, derived from dukkha, has acquired in modern everyday Khmer. But, on another level, dukkha comes from the suffering caused by 'impermanence' [anicca], according to which any state, any experience, any human relationship, however enjoyable, is marked by change and cannot last. Thus, change, inherent in the material world, causes suffering. Finally, at a third level of abstraction, dukkha designates the 'conditioned state' of things and beings, since existence results from a complex series of actions and reactions. Beings, including 'I' and 'self', are not actual entities, and do not possess their own existence. They are merely combinations of forces and energy known in doctrine as the Five khandas (in Pali 'aggregates' or 'constituent parts of a living body'). The 'self', in particular, is an illusion created by these 'aggregates', and therefore it should be discarded. The 'aggregates' that make up beings are perpetually changing and also create $d u k k h a$. Following the path indicated by the historic Buddha is to be impregnated with the 'Four Noble Truths', which show the way out of dukkha - the thirst for life and desire to perpetuate it peculiar to beings subjected to the conditioned state - and halt the 'cycle of rebirths' [samsara].

Suffering, as an experience directly linked to existence itself, is also part of the karmic vision of fate, which is profoundly individual. Karma, in its philosophical sense, is also the result of the theory of the 'conditioned state', in which life and fate evolve in a continuous process of cause and effect, action and reaction. Any action or thought produces 'fruits' [ phal] that finally ripen: that is, they have consequences in the present life or the subsequent reincarnations of individuals. Pain and illness may be bitter 'fruit' of this kind and the individual is alone in facing this karma, which he/she must 'redress' using the different ritual techniques at his or her disposal.

It could be argued that there is a considerable discrepancy between Buddhist philosophy and everyday practices, and that it is impossible to analyse the latter as a direct effect of the former. I think, on the contrary, that this Buddhist concept has a strong influence on the Khmer affective economy, even though simple villagers do not express it in the abstract terms that I have just used. In Cambodian social representation, the experience of suffering cannot be shared since it is a personal experience and differs from one person to another. I have had many opportunities to observe this fact, including outside the hospital, in villages or parts of cities where TB sufferers and HIV-positive people live.

This does not mean, of course, that 'suffering' cannot or must not be relieved, especially since, for Buddhists, neither suffering nor its more limited version as

10 This is a brief reminder that ancient Buddhist doctrine became diversified during the centuries following the death of the historic Buddha in $480 \mathrm{BC}$, dividing itself into different schools and being adopted by various societies outside India. After the eighth century AD, Buddhism declined quite rapidly in India, whereas it developed elsewhere, especially in Sri Lanka (Ceylon) in the twelfth century AD, in its Theravada form. 
pain has any redemptive or purifying function to make it desirable, in contrast to Christianity, in which the spirit is greater than the flesh. But the 'universal benevolence' that devotees of Buddhism must normally practise consists of paying non-specific, positive attention to all beings, in contrast to 'pity' and 'compassion' as described above. 'Universal benevolence' towards people and things does not require specific intervention for the reasons I have just given, but is the basis of feelings inciting people to help others. However, though these charitable acts towards a patient, for example - are among the good works [bon] displaying such 'universal benevolence', they are usually directed towards monks. Offerings of food, money or clothes are meritorious acts par excellence. Thus, karunā and the performing of charitable acts are not part of the therapeutic relationship as Cambodian doctors see it. Public charity is 'subcontracted' to those who seem to be directly concerned by it: that is, monks and aid workers.

\section{'Subcontracting' public charity to aid workers}

In Cambodia during the 1990s, public charity and poor relief were mainly the domain of the Buddhist monastery. 'Universal benevolence' is a sentiment expected especially of a monk and his female helper, the 'pious woman who has made Buddhist vows' [yiey chi]. ${ }^{12}$

Since they were neither members of an aid agency, nor monks or devotees who had pronounced the eight Buddhist vows, doctors and nurses left the care of cases they found too difficult to people from these two categories. Considering themselves as medical engineers whose speciality was taking care of the body, rather than caring for the spirit or relieving poverty, they expected aid workers to provide this 'spiritual extra', since the Westerners had chosen to come and help Cambodia - whereas Cambodians were caught up in a situation that they had not chosen. In the interviews I have conducted with doctors, they considered that they themselves could no longer afford to pay this benevolent attention to patients. According to some of them, post-Pol Pot Cambodia had become a hostile society where only the family circle counted.

The ideology of a 'medical vocation', another central element of the Western biomedical tradition, is based on the desire to save human lives. However, this vocation, as the Cambodians see it, is based on filial piety. When I asked doctors why they had chosen to study medicine in the first place, the first reason they gave was so as to be able to treat their own families and members of their own social network. Cambodian doctors therefore volunteer, not in hospitals like Western aid workers, but within the broad network of the extended family, where demands are frequent and difficult to avoid, often until late in the evening. The second reason given for becoming a doctor concerned salary - much higher than the local average. This reason, far from being taboo, is part of the identity of Cambodian doctors (and nurses) as biology technicians belonging to the new urban middle classes. By doing this, they reproduce, at hospital level, the government policy that implicitly subcontracts to aid agencies a public service that has gone down-

11 In the course of time, especially during the first decade of the twenty-first century, foreign and later Cambodian NGOs became the main actors in the care of the poorest populations. Cambodian Buddhism has itself undergone a change and a 'socially committed Buddhist' movement has appeared, sometimes working like the NGOs or financially supported by them.

12 Female ordination does not exist in Cambodia. 
hill since aid from socialist countries came to an end. This idea of their professional duties is in contrast to that of the aid workers, who for their part interpret these different objectives and values in terms of cultural differences or lack of training. ${ }^{13}$

\section{Implications for hospital work}

These differences in values, representations and objectives have direct implications for work in hospitals. I have often heard, especially in front-line surgical departments (so-called 'field surgery'), disillusioned aid workers expressing acrimonious regrets concerning patients who have died and who could have survived if the Cambodian staff had made the appropriate efforts. I myself witnessed the death throes of a beggar in front of the door of a Phnom Penh hospital, without a single member of the medical staff coming out to see what was the matter. In another hospital department, I saw a poor man with no family lying nearly naked for several days in his own filth on a straw mattress. Apart from these extreme cases, in day-to-day work, aid workers reproach their local colleagues for neglecting care and lacking concern, making the patients' lives an 'assault course'.

Collectively, Cambodian doctors have a tarnished image of their own profession, on account of the criticisms levelled at them by their foreign colleagues and by patients themselves. 'There's no point rushing round hospitals [to make observations]. You can write in your book that Cambodian doctors make people pay for treatment, mistreat patients and despise poor patients. That's all,' said one of them in a private conversation, a disillusioned woman doctor about to leave her country for Australia (1993). In private conversations, doctors blame the Cambodian 'character' [charet] or the rupture caused by the Khmer Rouge regime in the moral crisis said to be upsetting the Cambodian medical profession: 'Cambodians have a peculiar characteristic, you know,' continued the same interlocutor. 'Only money and honours [bon sak] are important to them. They despise the poor. It wasn't like that before Pol Pot.' This bitter self-criticism is accompanied by a confessed inability to change an overall system in which official proclamations and latent realities are in constant contradiction.

Cambodian doctors are constantly prisoners of doublespeak ('We would like to treat patients better,' but 'we don't have the means to do it'). Indeed, recently recruited members of the Cambodian medical profession, which has not had time to build up its own medical ethics and is subject to heavy restrictions in post-Pol Pot society, speak in more or less the same way as the aid agencies, but, on a daily basis, act according to the values of Cambodian society, where medical authority has no weight and the doctor-patient relationship is more complex than it appears at first sight.

\section{Distancing the patient}

Medical consultations are almost silent, apparently mechanical activities, with

13 In 1991, I suggested to WHO Cambodia that I could perform an anthropological field study on dysfunction in hospitals. The study would be based on observations of the interactions between all actors in hospitals, including aid workers. The person in charge of WHO's small office at the time replied that she was more in need of research on the cultural representation of diseases among Cambodian patients. According to her, hospitals were being deserted on account of this cultural difference. 
very little verbal or non-verbal communication between patients and doctors. This is, of course, partly due to the large number of patients, especially on outpatient wards where the doctor sees several dozen patients in the course of a few hours every morning, and can devote only a few minutes to each. ${ }^{14}$ But this model of biomedical therapeutic ethics is applied by all doctors regardless of the circumstances. The most striking example is that of Neang, a young woman doctor whose actions are graceful and gentle, and who is always pleasant and smiling, according to her colleagues. As soon as the consultation begins, her face closes up and her sentences become short and brusque. Although another doctor, Vireak, whose practice is several dozen kilometres away, is usually polite and friendly, he shows no empathy with patients and refuses to treat a late arrival who has run to the infirmary, because 'the consultation is over'. This woman will have to wait a week before seeing the doctor, who comes to this village infirmary only once a week.

The distance doctors put between patients and themselves in public hospitals is a form of protection against the urgent demands made of them that they are not able to satisfy, from their point of view - that of limited involvement in the hospital, since they have to work elsewhere to earn a living. Doctors or nurses reputed for their kindness are very soon overwhelmed with various grievances and pleas that require effort, time, or possibly money. Sometimes, the diagnostic and therapeutic limits of the infirmary or the dispensary are reached, and the practitioner has no choice but to advise the patient to go to the provincial hospital or to Phnom Penh, even when this is obviously impossible, as can be seen in the following case note:

'The patient is a forty-year-old woman, although she appears older since her physical appearance has greatly deteriorated. She has a shaven head [a sign that she is close to the Buddhist religion] and lives at the temple [the last resort for single women]. Vuth [the assistant doctor] knows her. She has an ovarian tumour and he has told her to go to Phnom Penh to have it removed, but she says she does not want to have an operation, according to him. For the moment, he is treating her varicose veins. The woman, in distress, keeps muttering stock phrases to all and sundry: "I'm poor; I no longer have a family". Malay [the nurse] looks at me with an embarrassed smile. The nurses smile at each other. As for Vuth, he is unshakeable. Each time she comes to see him, he repeats that she has to go to Phnom Penh for her tumour, and she replies "All right, I'll try and borrow a bike to go there". Phnom Penh is forty kilometres away by a poorlymaintained track. It is obvious that she will never get to the capital by this means. Vuth prescribes her something for her legs. She continues to complain to everybody without being able to attract anyone's attention, then she gets tired of it and leaves, dragging her feet.' (Case notes, District Dispensary, Kandal Province, May 1992)

Physical contact with patients is also very limited, even during a clinical examination. This usually consists of a short stethoscope examination, with the doctor

14 In a village infirmary (Daem Rih, Kandal Steung district, province of Kandal), where the doctor came once a week, I counted up to 60 consultations in two hours, or one consultation every two minutes on average. 
leaning over his desk, and a few rapid questions. The questions are stereotyped and require only a brief answer, in contrast to those asked during examinations by Western doctors from aid agencies - who maybe exaggerate this aspect for educational reasons. A diagnosis is also made quickly. From this point of view, the consultation is very similar to that of the kru khmaer [traditional doctor] who, similarly, makes a very quick diagnosis after asking the patient a few questions, without a clinical examination (except for traditional Chinese doctors, who take the patient's pulse). This distance between bodies is in direct contrast to Cambodian sociability between people of the same sex, which is, on the contrary, very tactile. Patients submit their bodies passively for examination and expose themselves to the doctor's scrutiny, without talking or asking questions, even when they do not understand.

This way of performing examinations by keeping the body at a distance and 'reading' it briefly from afar is based on reasons other than keeping at a distance from patients. One of these is fear of contamination, particularly from certain much-feared diseases such as TB and leprosy, leading to a repulsion that may in some cases become a phobia, especially among paramedics who have limited medical training. In some cases, there is a certain aversion to touching patients, who may have taken time off from the fields to come to the consultation, and have not had time to clean up after a long walk in the heat and dust. This is a form of class distinction, with 'white-collar' workers from the city reluctant to look after peasants. Without going into detail here about all the elements involved in this class relationship, I will simply mention that the term designating cleanliness [sa-at, 'clean'] also means 'beautiful' and 'gleaming' and is associated with light-coloured skin and social class. Faced with this gulf between carers and cared-for, patients have developed a variety of strategies for getting medical attention.

\section{Patients' strategies for obtaining care}

Hospital patients have a whole range of strategies for obtaining access to care and are not entirely without resources in the face of doctors who keep themselves at a distance, make them pay (sometimes a lot) for reputedly free treatment and work in a general context of shortages. The first technique, even for the poorest, consists of secretly bargaining for the sum paid, and enables patients to express their wishes and make their choices known, usually for the prescription of a lot of medicine.

Another method is for the family accompanying a hospital patient to make frequent demands on all staff, Cambodian or foreign, that they come across, since frequently asking for diagnosis and medicines gives rise to the hope - often justified - of getting a little by asking for a lot. In these demands, the poorest use the ritual technique of appealing to 'universal benevolence', which is a socially legitimate form of request for help. The body language used - the back bent in sign of humility, or even prostration, the hands joined at the level of the chest or forehead, the chanting voice - can be found in other situations where a Buddhist gift is requested or obtained (beggars in the street calling to passers-by, old women living in monasteries, yiey chi, receiving money from the faithful). This is a form of (socially unequal) exchange, as this ritualized appeal to generosity will bring material and physical benefit to the patient in exchange for religious benefit to the 
carer, since the gift is a form of acquisition of Buddhist merit [bon] in the concept of karma. ${ }^{15}$

Beyond the religious aspect, the appeal to 'universal benevolence', on the social scale, deeply implicates differences and inequalities between individuals since gifts enhance the prestige of the giver, whereas the medical ethics to which Westerners adhere insist on equality in the face of disease and suffering, along with the necessity of treating everybody the same way. This permanent search for care in hospitals and the role of seeker of care are exhausting for patients and their families. This is what I was told by a discouraged 53-year-old man, whose wife was in hospital in Phnom Penh with ascites (effusion of liquid in the abdomen caused by cirrhosis of the liver), as he saw her condition worsen: 'Last night, my wife nearly died. I decided that ... never mind. If she's going to die, she will die [slap, slap teuo]. I'm tired of running after doctors.'

In this race for treatment by patients and the distance from them established by Cambodian doctors and nurses, patients occasionally inspire a feeling of aneth in medical staff. Unlike 'universal benevolence', aneth is a feeling inspired by a particular person whose misfortune has touched us. But it does not imply identification with this misfortune, any more than does the former. It leads to a sentimental impulse that may become affection or even love. For example, one of the favourite subjects of popular novels and videos is a love affair between a rich girl and a poor boy (nevertheless in possession of exceptional personal qualities, including physical beauty, the sign of a great future). The girl's first feeling for the young man, which will lead her to love him against her parents' wishes, is aneth, a mixture of seduction, compassion for his hard life and admiration for his qualities. In this way, a person for whom we feel aneth usually possesses remarkable personal, physical ${ }^{16}$ and moral qualities, and struggles hard to live despite his poverty or all kinds of difficulties.

Finally, the presence of an NGO in a hospital provides an opportunity for patients to devise new strategies to obtain treatment. Westerners introduce a different model of behaviour with regard to patients: longer and more detailed questions, a more thorough physical examination, guaranteed free treatment and empathy with the sick. This contrast with the behaviour of Cambodian medical staff has highlighted patients' dissatisfaction and demonstrations of impatience with local practitioners. This was the opinion of a woman who had crossed the whole country from Kandal province to the Site II refugee camp on the Thai-Cambodian border, to seek treatment for her baby suffering from serious pneumonia - help that unfortunately arrived too late. She intended to stay in this refugee camp where the hospital was run by a foreign NGO, leaving behind her husband and three other children, since she herself was ill.

'I was in hospital in K. for twenty days, then Hospital X in Phnom Penh for a month and twenty days. In Cambodia, nobody takes care of sick people if they are poor. I was told "you need three chi [of gold] to get better". In fact, I spent

15 In Khmer, the term is usually translated as 'thank you', o kun, which means literally '(I am) happy (for your) merit'. The beneficiary of the gift contributes to the karmic elevation of his/her benefactor.

16 Physical qualities are never anodyne, since they are at once part of an interpretation of the 'signs' written into the body as marks of destiny, and of popular morpho-psychology associating physical and moral characteristics. 
two damlong [that is, twenty chi, or 67.4 grams of gold]. Here, in this camp, you don't have to pay for the hospital. It's free. I'll only go home if I have to, when we are repatriated [under the aegis of the HCR in 1993].'

As a last resort, patients can leave, and it frequently happens that, during their morning visits, staff find empty beds, deserted at first light.

\section{Social roles}

Hospitals are not therapeutic islands isolated from the local social life. On the contrary, patients assume social roles that have an influence on the therapeutic relationship. The ideal of universalism and affective neutrality in the doctor-patient relationship, valued by aid workers who are outside the Cambodian social structure, is thus put at risk, since the Cambodian doctor-patient relationship is, on the contrary, part of local social hierarchy and social relationships. Negotiations between aid workers and Cambodian staff are therefore also related to favours granted to certain well known patients, such as avoiding the queue and obtaining free medicine or a longer consultation. In contrast, a patient with marginal or disapproved-of social behaviour may be rejected by the staff of a dispensary, as clearly illustrated by this example:

'A new patient, a young woman aged twenty-eight, arrived in the unit with horrific burns. She was living with a married man and his lawful wife had thrown acid at her while she was asleep. This is not an unusual punishment. Noëlle [a nurse] told me angrily: "This patient arrived on Sunday [four days earlier]. They [the Cambodian staff] left her in a corner and did nothing to help her. When I saw her on Tuesday, I began treating her. Until then the only treatment she had had was lime on her face [put there by the family]. Now the [Cambodian] nurses are putting on dressings." Noëlle kept a close watch on the care given to this patient by Sethavy [a nurse]. When she considered her work finished and was beginning to put everything away, Noëlle called out harshly: "Hey! You haven't finished, there's still her head left to do!" The nurse finished the job without saying a word, her face expressionless.

Later, in the consulting room, the Cambodian nurses were talking about this burn victim. "She's just a troublemaker, and what has happened to her is her own fault: she went to insult his wife because the wife had asked her husband to come and see his sick child." Noëlle, who had meanwhile come into the room, had this translated, and protested: "For us, any patient who arrives at the hospital must be treated, we cannot let anyone suffer, and their reasons for coming are secondary." One of the nurses answered, in a low voice, in Khmer (which Noëlle did not understand) "Look after her yourself, then!" "You see, Noëlle, what if his wife comes and sprays you [with acid] in the hospital?" said another nurse.' (Case notes, Kandal Province Dispensary, May 1992)

Hospital care and treatment therefore appear to constitute one of the complex social 'products' of interactions and negotiations, both at macro-social and local levels, between Cambodian staff - who cannot really work without foreign help in times of shortage - Western aid agencies and patients. 'Social products' in this case do not mean harmonious integration or consensual completion of negotiations. 
On the contrary, humanitarian aid is strongly instrumentalized, and the Western actors who provide this aid are kept away from the centre of the hospital's therapeutic and extra-therapeutic activities by means of various social techniques. The cultural and professional motivations of Cambodian and Western staff are not fundamentally so very different. According to circumstances, they coincide, are manipulated, or are completely opposed, the discrepancy coming partly from the fact that humanitarian ideology over-determines Western medical values (frugality, poverty management, valorization of basic medical treatment), whereas Cambodian medical practitioners, as underpaid civil servants working for an authoritarian government, do not feel responsible for the public good.

\section{References}

Arendt, Hannah (1963), On Revolution, Viking Press, New York.

Atlani-Duault, Laetitia (2009), Au bonheur des autres. Anthropologie de l'aide humanitaire, Armand Colin, Paris. [English version (2007) Humanitarian Aid in Post-Soviet Countries. An Anthropological Perspective, Routledge, London and New York].

Au, Sokhieng (2011), Mixed Medicines. Health and Culture in French Colonial Cambodia, University of Chicago Press, Chicago, IL.

Boltanski, Luc (1999), Distant Suffering. Morality, Media and Politics (first published in French, 1993), Cambridge University Press, New York.

Chan Sucheng (2004), Survivors. Cambodian Refugees in the United States, University of Illinois Press, Urbana and Chicago, IL.

Crochet, Soizick (2008), 'La santé au Cambodge: histoire et defis', in Forest, Alain, ed, Cambodge contemporain, IRASEC/Les Indes Savantes, Paris.

Fassin, Didier (2011), Humanitarian Reason. A Moral History of the Present (first published in French, 2010), University of California Press, Berkeley, CA.

Freidson, Eliot (1970), Profession of Medicine. A Study of the Sociology of Applied Knowledge, University of Chicago Press, Chicago, IL.

Goffman, Erving (1967), Interaction Ritual, Anchor Books, New York.

Guillou, Anne Yvonne (2009), Cambodge, Soigner dans les fracas de l'histoire. Médecins et société, Les Indes Savantes, Paris.

Hughes, Everett (1958), Men and their Work, Greenwood Press, Westport, CT.

Ke, Bunthoeurn (2011), 'Legal framework of NGOs in Cambodia', International Journal of Not-forProfit Law, Vol 13, Nos 1-2, website: http://www.icnl.org/research/journal/vol13iss1art_1.htm\# _edn1 (accessed 24 April 2013).

Olivier de Sardan, Jean-Pierre (2005), Anthropology and Development. Understanding Contemporary Social Change (first published in French, 1995), Zed Books, London and New York.

Ovesen, Jan, and Trankell, Ing-Britt (2010), Cambodians and their Doctors, NIAS Press, Copenhagen.

Parsons, Talcott (1951), 'Social structure and dynamic process: the case of modern medical practice' (Chapter X), The Social System, The Free Press of Glencoe, New York, pp 428-479.

Ponchaud, François (1978), Cambodia: Year Zero (first published in French, 1977), Holt, Rinehart and Winston, New York.

Shawcross, William (1984), The Quality of Mercy: Cambodia, Holocaust and Modern Conscience, Simon and Schuster, New York.

Starr, Paul (1982), The Social Transformation of the American Medicine. The Rise of Sovereign Profession and the Making of a Vast Industry, Basic Books, New York.

Strauss, Anselme (1978), Negotiations. Varieties, Contexts, Processes and Social Order, Jossey-Bass, San Francisco, CA. 